\title{
Psychological Training: Effect of Cognitive Stereotypes of Interpersonal Relations in the Sphere of Family Relations and Business Communication
}

\author{
Sumovskaya Elena Josephovna ${ }^{1}$ *
}

\section{ABSTRACT}

Various aspects of psychological influence of cognitive stereotypes as phenomena of social psychology reveal, the analysis of ways of influence, mechanisms of social and psychological impact on the identity of teenagers is given.

Keywords: The Psychological Training, Mental Phenomena Which Are Staticized Unconsciously Among Teenagers, A Cognitive Stereotype, A Symbol, A Metaphor The Interpersonal Relations, The Subject Of Psychological Influence, Object Of Psychological Influence, The Communicative Environment, Infection, Imitation, Belief.

Psychological trainings: Application of cognitive stereotypes and symbols as a part of metaphors for correction of behavioural, communicative and emotional patterns of the interpersonal relations among teenagers.

Stereotypes of family relationship at teenagers are formed under the influence of various mental factors influencing the affective and strong-willed sphere. It is no secret that crisis states in society were always followed by manifestations of cruelty, indifference and cynicism, and as a result, spiritual degradation only confirmed destructive tendencies among teenagers. Daily public life appears every day in examples confirming this sad tendency and absence of elementary knowledge of the nature of the interpersonal relations. For the most effective use of active group methods of influence application of cognitive stereotypes and symbols as a part of metaphors can become that "a stick - a lifesaver" which will solve many of actual problems in daily activity and the interpersonal relations of teenagers, as in the sphere of the family relations, and business communication. If not to take the effective measures directed to prevention of crisis states in society of idea of the humane relations to each other and will remain ideas. The majority of actual problems of the interpersonal relations among teenagers can be solved by means of "live

\footnotetext{
${ }^{1}$ Master of II course, the direction of preparation 37.04.01 Psychology, Department of humanities LEU VPO

"International Innovation University", Sochi

*Responding Author

(C) 2016 I S Josephovna; licensee IJIP. This is an Open Access Research distributed under the terms of the Creative Commons Attribution License (http://creativecommons.org/licenses/by/2.0), which permits unrestricted use, distribution, and reproduction in any Medium, provided the original work is properly cited.
} 


\section{Psychological Training: Effect of Cognitive Stereotypes of Interpersonal Relations in the Sphere of Family Relations and Business Communication}

knowledge", many of which are present as myths at folklore and are valuable empirical experience. Even more often psychologists, trainers adapt this experience to the modern world, and consider him as tools. Correctly planned psychological training in recent years, became one of the most common forms of psychological practice. Being system of specially organized influence, he contains theoretical and academic knowledge which is used at intensive psychological influence. The science psychology has all tools by means of which it is possible to give the effective help directed to elimination of the crisis phenomena in general. The famous British philosopher A. N. Whitehead claimed that "the civilization moves forward by increase in number of operations which we can carry out, without deliberating over them" $(1999)<\ldots>$ Unfortunately, all modern education system is focused on the raised verbalizm and intellectualism of training, to the detriment of development of emotions and feelings, and also their bases - figurative thinking. $<\ldots>$ it is impossible to Understand the complete world only by means of symbolical (mythological) dialectics, mythological thinking which perceives the world completely (syncretic manner). Means of such thinking is the symbol. From the point of view of rationalistic thinking we won't explain a symbol as it is transcendental. In science the symbol "is reduced to the level of a sign of simple designation, the label hung on objects and the relations of the real world $\ldots$ but it is not a symbol, but the dead scheme $\ldots<$ any more $\ldots>$ the Symbol is synthetic by the nature. He represents indissoluble unity sensual and rational: the image in it is idea, and idea - image. At decomposition for the image and idea, a symbol disappears (A. Kosarev, page 64,65,92). The main gnoseological function of a symbol - to interpret and generalize. In this sense the symbol is concrete and sensual generalization of objects and phenomena of reality." [1].

The relations of people are influenced by their values. Among teenagers coincidence of the main vital values strengthens relationship, the divergence or the conflict of values threatens this relationship. G. A. Berulava in the collective monograph "Role of Stereotypes of Mental Activity in Development of the Personality" notes: "Stereotypes of mental activity it is the mental phenomena which are staticized unconsciously. They can be cognitive, behavioural, communicative and emotional. Cognitive stereotypes - the steady cognitive schemes connected with concepts of installation of implicit knowledge. At implicit knowledge a priori there is a strategy of a solution. Thus, cognitive stereotypes are formed within the solution of practical problems and, respectively, are connected with such form of thinking as practical thinking, unlike his such form as formal and logical. Cognitive stereotypes are undoubtedly formed as a result of accumulation of a certain sociocultural experience. If the formal and logical thinking which is formed and represented in the course of organized training uses generally symbolical information, then practical thinking which is the cornerstone of formation of stereotypes of mental activity, is guided more by figurative, nonverbal information. $<\ldots>$. Experts focus attention long ago that "actually automatic, stereotypic behavior at people prevails as in many cases it is the most expedient, and in other cases - it is just necessary ((Bodenhausen \& Lichtenstein, 1987). The kernel of relationship consisting of two representatives of the human 


\section{Psychological Training: Effect of Cognitive Stereotypes of Interpersonal Relations in the Sphere of Family Relations and Business Communication}

race, the man and the woman plays very important role in the sphere of family and business communication. The methods influencing formation of a communicative kernel were known from time immemorial. For today the condition of a kernel of relationship requires to itself special attention, and it is necessary to begin correction of behavioural, communicative and emotional patterns of the interpersonal relations, in my opinion, among teenagers. As an example of forming of qualitative relationship and introduction of the practical contribution, I provide the head from the family legend which is prepared for printing which helps till present members of my family, to make a right choice, to make important vital decisions and to live, bringing benefit to society:

\section{INTRODUCTION:}

As not enough time is necessary for us for decision-making, influencing all course of life. Three representatives of the human race is two men and the woman on the river bank recently made decisions, everyone the. One fought for the happiness, the second - couldn't afford it. The woman has made the choice. Everyone made the decision and has received result. The woman symbolically became the Soldier Hunter's half, having enclosed the hand in his strong hand which will remain with her until their hearts fight. The soldier Hunter, having felt tenderness and warmth of a female hand, never in life will refuse the choice and won't allow someone to overstep for him the limits. The woman has for the first time felt confidence, support, protection, respect, understanding, devotion, trust and hope for the future. The decision of the woman to give preference to the Soldier Hunter was unexpected. For such short period, the Soldier Hunter has suddenly understood what value he has, what he dreamed of came true, and the way seemed easier and joyful. The soldier Hunter and the Woman have left afar on the coast of the big river. The woman conducted the Man to the parental dwelling. The issue of the choice is resolved.

In midday heat on the river bank, hum of cicadas, fluttering of birds over a dry grass is heard. The sun costs highly - birds exchange words about the life, all live has started moving. The free Traveller remained one, events didn't keep within in his consciousness: What has he made not so? Why the woman has chosen not him? The brain refused to understand and host the events which have happened on the river bank.

From the author: "Eternal question: "Why?" - we set to ourselves in difficult situations. Giving a huge number of options, our brain as a supercomputer, looks for answers, convenient for us. But that receive the desirable can wonder better: "What it is necessary to make?" or "How to change a situation, and it is possible also itself?". When we are refused in the relations? More often when heart is silent and the partner is necessary to us only for some purposes, and if we ask a question: "Why?" - it is clear that such feelings are superficial and are quickly forgotten.

Having recovered, the Free Traveller has raised the head and has looked at the clouds floating on the sky, such far and unattainable as the woman who has left afar. All life he will remember the 


\section{Psychological Training: Effect of Cognitive Stereotypes of Interpersonal Relations in the Sphere of Family Relations and Business Communication}

first lesson presented to him on the bank of the wide river where the tranquility has again set in, and the world opened the ways. Having looked back, he has suddenly seen one more female figure disappearing in a high grass behind a hillock. With interest he has begun to look narrowly and has understood that watch him. The free Traveller has sat down on a hillock, and now natural sharpness helped it to understand a situation. Showing cunning and dexterity in the treatment of women, he much quicker, than skilled hunters, I tried to obtain their arrangement. And now, having rolled down down a dry prickly grass, he has decided to learn everything, watching from shelter the woman disappearing in a dense and high grass. Trying to make out an event, it seemed to her, she watched the events imperceptibly for all. Having lost from a type of the Free Traveller, she came to a glade, and the Free Traveller, having quickly estimated a situation, has this time decided not to hesitate. The woman was young and beautiful and, with all passion of a hungry animal he has brought down her from legs and two young bodies, have rolled down in a small depression in the ground where having felt hot breath and tenderness, the Free Traveller has tried to forget the pain which was breaking off his heart and reason. The girl, having given in to male persistence, gently I looked the Free Traveller in the face.

But, something was not and, having enjoyed much, he didn't want embraces and tenderness any more. Having shaken off a dry grass and leaves, he quickly left, almost run overcoming a hillock behind a hillock ... The young woman, badly understanding a situation, I have tried to follow at him ways, to take the Free Traveller by hand, showing a beautiful body, hair ... Very clearly she asked it to remain, but the Free Traveller hurried: in his stomach it was empty, in the head images of people and places where it will receive food and heat were already born, to bear responsibility for someone, even out of gratitude for had a good time to it there was no wish. Cicadas sang, midday was included into the rights. The young woman observed the Free Traveller leaving afar, felt loss, a devastation ... That in whom she has trusted and has presented the tenderness, left afar, leaving her alone with the thoughts. I have led her excessive curiosity and interest in others problems to a sincere wound and pain from a mistake and wrong act. In vain the spent time for contemplation of others life... Others experience was useless and now she regretted that she couldn't avoid this moment in the life. Maybe it would be better to leave problems to their creators? Always there is a choice and if a choice is made correctly, we will have new opportunities and we will learn to avoid hit in whirlpool of passions and to a devastation of the soul. How to learn to make the choice how to learn to thank how to learn to appreciate friendship, love, and to bear responsibility for the actions? - Very often we forget to ask these questions to ourselves, doing the acts devastating other people .

The free Traveller hurried now, in his head images of other women, beauty of their bodies and eyes already flashed. He didn't suspect that the most important event which he won't be able to forget for the rest of the natural is refusal of that which has chosen not him, and shout, the wild shout of the Soldier Hunter causing horror in his consciousness which, as well as refusal, forever will remain in his memory. For the first time breast pain haunted him, the feeling earlier 


\section{Psychological Training: Effect of Cognitive Stereotypes of Interpersonal Relations in the Sphere of Family Relations and Business Communication}

unfamiliar has taken the place in his heart. There was a wish to get rid, escape from this feeling, but where? For a minute he has stopped, has looked round on the passable way, around there was an emptiness reminding to him of loneliness, and soon he has taken to the heels along the river, wishing to appear quicker on a glade at a mountain foot. Run on the twisting footpath in mountains which is lost in a dense grass has taken away many forces, at last it has risen upward, by a ledge of the rock of the cave, and long wandered around the flaring center, looking at cave walls, thinking of an event. He remembered the studying woman's look, and didn't understand why she has trusted in the rival who easily has given up the production to her legs. He considered the Soldier Hunter's act unreasonable, and it is more beautiful and much cleverer than him, never in the life had he just given the production to anybody. Why?! Why?! Why?! Questions at him in the head rushed. The rage prevented it to concentrate, the feeling of loss prevented to think of food, of new hunting, the family.

At a cave on a height the excellent view of the settlement where there were those two who have brought pain to his heart opened. From here his tenacious look has made out couple which went on the hill along the river. Their silhouettes attracted a look, and it fixedly observed their way on a footpath, representing itself (himself) on the place of the Soldier - the Hunter, hating the fear which has prevented to become darling. Desire to submit women again and again, has lodged at it in thoughts which excited him a brain, adjusting on search of the answer to an eternal question: Why this woman has trusted not in him? Standing on a height, he has understood that the Soldier Hunter won't be able to interfere with anything to him, and now he will be able to express the feelings. Never earlier he shouted, before he didn't even hear the voice. And the Free Traveller has cried! Shout by his free echo has reached the loving couple going on the river bank. This shout he tried to prove to the rival the superiority and ingenuity.

It was from far away visible that the Soldier Hunter has heard shout. Having shortened steam stride, I have descended from a footpath and I have sat down under the stretched branches of the old tree growing at the river. Having noticed changes on a serious face of the Soldier Hunter, the woman has gently put the head to him on a shoulder. Shout of the rival has responded in heart unpleasant reminiscence, but looking at the companion, he has understood that he can prevent now nothing to them, near him that of which I dreamed and which I valued ... On the bank of the big river the settlement lived life, the easy smoke streamed from the centers and huts. The woman conducted the darling to a home.

\section{WARRIOR WOMAN (POWER AND INDEPENDENCE)}

Serene silence of the settlement which has taken cover behind an easy gray haze of fires shout of the Free Traveller has woken ... Having heard this invocatory shout, despite of late time, the danger proceeding from the wood and wild animals, several young women from the settlement have directed through the wood on a footpath to how it seemed to them, the only thing which was so beautiful in beams of a decline and called her. It seemed to everyone that it will become 


\section{Psychological Training: Effect of Cognitive Stereotypes of Interpersonal Relations in the Sphere of Family Relations and Business Communication}

his love for the rest of life! It seemed to everyone that this shout is addressed only to her, it awakened in women, something natural, not controlled by consciousness, wild, passionate. Invocatory shout of the man conducted beauties in the wild wood teeming with dangers. Each of them represented a rough meeting, delight from possession with each other.

The footpath which is running away in the wood was an iskhozhena, a set of human legs which went on her to darkness, uncertainty, danger. Under impression of future meeting of the woman didn't think of themselves, the forces, making the decision to start on such dangerous journey alone. Some were stopped by parents, having caught up with beauties, in love with illusion, and, in the different ways having returned to the settlement. Some became the victims of wild animals, by inexperience having got into their paws, and those which at a mountain foot nevertheless have come out of the wood, became competitors. They dreamed about is mute! At the long nights muffling up in skins of the killed animals, eating berries of wild plants, battling against predators and own fears, they cultivated in themselves spirit - spirit of the SOLDIER who rescued them from danger, installing in their souls force and courage, dexterity, abilities and knowledge of the hunter. Shivering from cold and fear, winning victories in cruel battles for production, women asked themselves the unique question: "Why I am one?". Thoughts and the analysis of the decisions passing into monologues which stream couldn't be stopped came later: "He saw that I go to him, through this wild wood ... He called only me ...Why do I alone fight in this wood?", and a question which didn't leave reason when the compelled loneliness frightened by the hopelessness: Where are you?" I didn't give any answer, nobody was still near. And soon in one of the days similar at each other incessant fatigue and hunting behind livelihood, without receding and without refusing the chosen way to the darling, the Female Soldier has seen a gleam in the wild wood and it seemed to her that she has seen the man's silhouette ... Having flown in dense foliage, this silhouette was dissolved as a mirage in a thicket and was similar to a silhouette of that only thing who was drawn by her imagination in long searches of a way in the wood. But it the foot of the mountain which attracted to itself fancy silhouettes of the low trees similar the crooked trunks and branches, on people with the hands raised up had only a glade. Roots of trees it is tenacious grabbed the stony soil, for many years, trying to fight for curative moisture and the place in the sun. This glade has been filled in with light and attracted to itself raznotsvety, a smell of fragrant herbs, heat and serene rest. The woman has looked in the sky where clouds still slowly floated, the solar glade at a foot of the mountain called to itself and conducted through small young growth to the footpath which is running away upward to mountains, showing a way further, there, where he lived - her dream, the one who so beautifully and invitingly shouted in decline beams.

Having come out of the wood, it is covered with production, with onions and arrows atilt, squeezing a spear a strong hand, the woman went on a footpath, anticipating a meeting. But, when the dream was very close, the unpleasant surprise expected it. At this moment, she has suddenly seen one more, same beautiful and strong woman at whom production was twice more 


\section{Psychological Training: Effect of Cognitive Stereotypes of Interpersonal Relations in the Sphere of Family Relations and Business Communication}

and she ran up a tropic quicker. Both women, having noticed each other, have stopped for an instant, and later, having looked round on the district and, having estimated each other, have very much rushed competing in speed upward to a cave, being torn, through dense thickets of the bush which is found on the way from time to time. Women ran very fast to that whose image warmed at the long lonely nights, losing production, scratching a body about prickles, forcing down legs till it bleeds, they ran to that, the only thing who was so beautiful in decline beams. Run on the mountains has deprived of the last forces and, having realized that all the same the man will choose one of them, the woman have stopped. In the place open all to winds, on a mountain ledge the sun burned down a surface, the high sky added determination, the birds who are promptly taking off from under legs, round stones under legs, sliding in an abyss created instability at the movement. The moment of truth came to a point which was in not crossed border of own despair where everyone fought for superiority of own ego and the concession was regarded as defeat, the feeling of alarm was rolled by waves, and, not in forces to reconcile to loss of own illusion, women have started a bloody fight .

Having covered with wounds gentle bodies sharp copies, having broken hunting tools, not having conceded each other in anything, they have ended bloody fight when fatally wounded competitor lay at legs of the winner of the Female Soldier ... Wounds burned down with wild fire a body ... And suddenly, having raised eyes on a rock ledge, in beams of the coming decline the Female Soldier has seen him! It was he, her dream, favourite illusion which was drawn by imagination in long searches of a way to his cave! And now he nearby, and that? His indifferent eye is turned somewhere afar! This look put more wounds her to heart now, than all burdens of travel. He saw all: cruel fight and its victory! Why he has turned to her a back? She has come to him and production at her twice more now! She is worthy respect, at least, of praise for the act!

But where his eye is turned? Having looked back, towards the settlement - to her look what she even didn't guess has opened, his eye has been turned on usual couple of people sitting at the river. Even it was from a distance possible to understand that it is couple of lovers ... And suddenly she has understood that his shout has been addressed not to her, and he called that that so gently I looked at the man, that whose body was without grazes and bruises, that to which her beloved brought gifts.

On a ledge it became silent ... The sun stood in a zenith. The birds who have become silent during a bloody female fight have begun to make habitual sounds again. The female Soldier having grown weak, I have sat down on the dusty, mixed with sand pebble, skin of legs has felt a rigid surface of a stone scattering, fight is ended, the objectives are achieved, but there is no

pleasure. The death of the competitor prevented to find rest in soul, not so she represented this long-awaited meeting with the one who was her ideal of beauty and forces ... 
At last the Free Traveller has torn off the look from a loving couple and with pity has looked at the winner. Having given her first aid, he has lifted her on hands and has transferred to the ledge which was is a little higher at an entrance to a cave, and, having come back for fatally wounded competitor, he has managed to close only her beautiful eyes in love. The death has for the first time visited the dwelling of the Free Traveller. The next morning, healing wounds to the Woman - to the Soldier, he has for a while forgotten about that that and I remained with him in memory an ideal of beauty and tenderness."

Decades in the modern world society formed at the subject of belief, approving achievement of superiority over others. Achievement of the purpose at any cost is widespread desire among teenagers and, in my opinion, leads to one-sided development of society. Without penetrating into the nature of the mental phenomena of other participants of vital process, teenagers, unfortunately, make mistakes which are reflected in their communicative environment, leading inexperienced representatives of teenagers to the conflicts. For forming of positive tendencies and accumulation of practical experience and desire to investigate a communicative kernel, and also for continuation of discussion about symbols, and their updating in the modern world, as an example I will present a communication kernel, in such look in what it passed from father to son in my family. Red strelochka have determined the direction of personal growth, and flexible black - partner communications: continuous - ideal, faltering - imperfect.

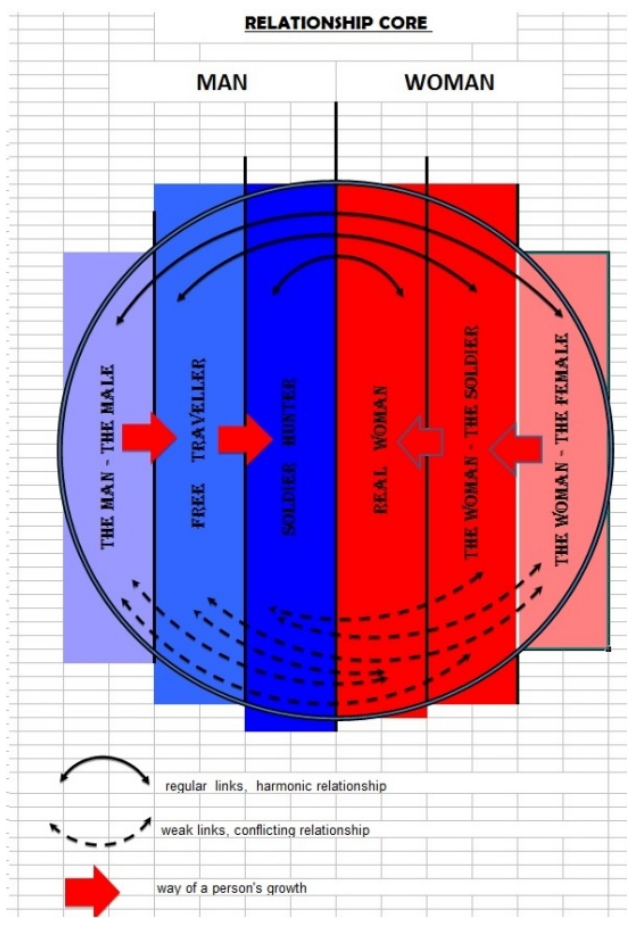

Fig. 2. A communicative kernel in the sphere of the interpersonal relations "female male" (initial material Sumovskaya E.I. family has provided.) 
According to the well-known scheme N. V. Matyash (fig. 1) [2]: infection - suggestion imitation - belief, the actions proceeding from emotions and directed to thinking in my opinion nevertheless is possible to correct a situation in society.
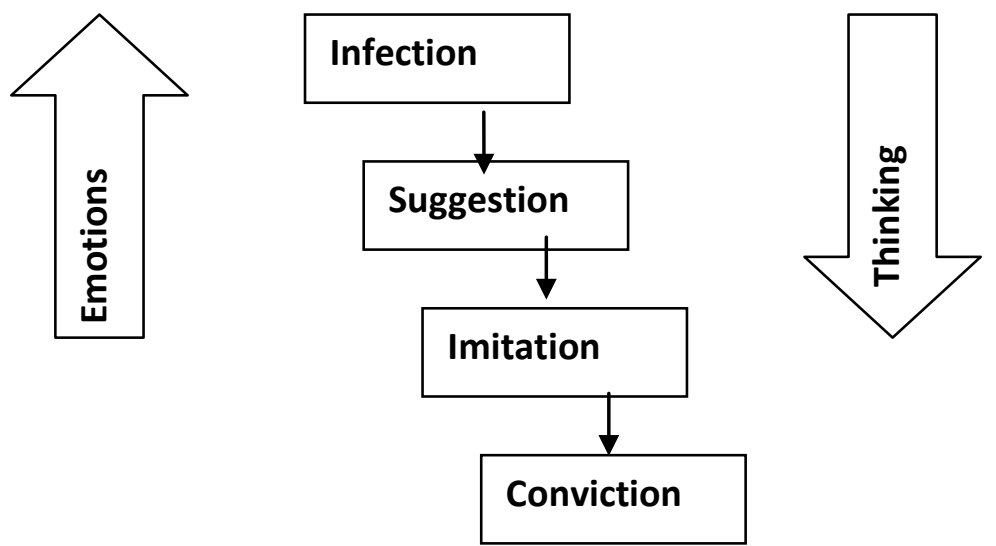

Fig. 1. Ratio of mechanisms of impact on the personality and their communication with emotions and thinking

It is known that any science becomes attractive to studying when the advantage of its application is obvious. I won't open a secret if I express expectations of the colleagues working in the field of group methods of influence that is in the field of psychological trainings: psychologists, kouch, trainers who dream of the instruments of psychological influence helping to form in the way of implicit knowledge emotionally - valuable experience which many subjects have due to the lack of elementary even no initial knowledge of practice of the interpersonal relations and consequently, and generating crisis situations in life. I sincerely hope that the "live knowledge" available to my family and passing from father to son, will give help and notable advantage to people which identity was created out of the sphere of the family relations. . Certainly, in one article it is impossible to capture all range of the processes happening in the sphere of the interpersonal relations "the man - the woman", however I hope that this material at least will generate discussion and discussion. Making use of experience of last generations it is possible to activate positive changes in society, but single efforts of patriotic psychologists and trainers there isn't enough.

\section{LINKS TO SOURCES:}

1. Berulava GA Berulava MM Botasheva ZS, Nepsha OV Sagilyan EM, Splavskaya NV (under the general editorship Berulava GA) role stereotypes of mental activity in the development of the individual: collective monograph. - M.: Izdat. Center "Humanities", 2009.-S.7,64-157s.

2. Matyas NV Methods of active social-psychological training: Textbooks / NV Malyash, T. Pavlova. - 2nd ed., Sr. - M.: Izdat. center "Academy", 2010. - P. 13. - 96. 